\title{
Pioneering DUTCH SCHOLARShIP ON HISTORICAL INDOLOGY AND LINGUISTIC SCIENCES
}

\author{
Tej K. Bhatia \& Kazuhiko Machida \\ Syracuse University, New York \& Tokyo University of Foreign Studies
}

\section{Résumé}

Tandis que les contributions allemandes, britanniques et indiennes à l'histoire de la linguistique ont été prises en compte à leur juste mesure, le rôle des Néerlandais reste relativement peu étudié alors même que ce sont eux qui ont fondé la tradition grammaticale hindi. La première grammaire du hindi fut rédigée par Jean Josua Ketelaar (1698) en néerlandais. À partir d'une étude de son manuscrit resté inédit, cet article soulignera le rôle des travaux linguistiques en néerlandais pour la théorie et la pratique de la communication interculturelle et des sciences linguistiques, en insistant sur la manière dont la grammaire de Ketelaar: 1 . a fondé la tradition grammaticale (hindi-hindoustani) indienne au XVII ${ }^{\mathrm{e}}$ siècle 2. Preparé le terrain pour le développement des méthodes historico-comparatives et 3 . nous renseigne sur les motivations à apprendre une langue étrangère, et sur l'épistémologie et la communication interculturelles générées par les forces de la mondialisation à l'époque coloniale.

\section{Mots-clés}

Contributions néerlandaises à l'indianisme ; grammaire la plus ancienne du hindi ; tradition grammaticale hindi ; Jean Josua Ketelaar (1698) ; traditions lexicographiques européennes (dictionnaires) ; méthodes historico-comparatives

\section{Abstract}

Although the Dutch pioneered the Hindi grammatical tradition, it is ironic that while the German, British and Indian contributions to the history of the linguistic sciences have been adequately accounted for, the Dutch contributions remain a rather neglected area. The first grammar of Hindi was written by Jean Josua Ketelaar (1698) in Dutch. Based on his unpublished manuscript, the aim of this article is to underscore Dutch linguistic scholarship for the theory and practice of cross-cultural communication and linguistic sciences, primarily in three areas: 1 . In pioneering the grammatical tradition of India, namely HindīHindustānī grammatical tradition in the seventeenth century; 2 . In setting the stage for the development of comparative historical methods; and 3. In providing insights into motivations for foreign language learning and into the epistemology and cross-cultural communication triggered by the forces of globalization during the colonial era.

\section{Keywords}

Dutch contributions to Indology; Oldest Grammar of Hindi; Hindi Grammatical Tradition; Jean Josua Ketelaar (1698); Indic dictionary tradition; European dictionary traditions; Historical-Comparative Methods 
Contrary to the widely held belief by historians of Hindī grammar, the first grammar of Hindī-Hindustānī ${ }^{1}$ was written neither in English nor in one of the other Indian languages. Its creator was neither an Englishman nor an Indian. The pioneering grammarian was neither a missionary nor someone with expertise in linguistics or languages. Who was he? Why did he write the grammar? What were the circumstances which inspired him to undertake this challenging work? What was it like writing a vernacular grammar in the era of the discovery of India? What was its nature and organization? We attempt to answer these questions based on Jean Josua Ketelaar's unpublished manuscript, which dates back to 1698. In addition to these questions intrinsic to the grammar per se, the aim of this article is to underscore Dutch linguistic scholarship for the theory and practice of cross-cultural communication and linguistic sciences, primarily in three areas: 1 . In pioneering the grammatical tradition of India, namely Hindī-Hindustān̄ grammatical tradition in the seventeenth century; 2. In setting the stage for the development of comparative historical methods; and 3 . In providing insights into motivations for foreign language learning and developing tools to gain insights into the epistemology and cross-cultural communication triggered by the forces of globalization during the colonial era. In order to achieve these three goals, an in-depth analysis based on the oldest grammar of "Hindustani", the cover term used by Ketelaar for both Hind̄̄ and Hindustān̄̄ (The Hague Manuscript) written by Jean Josua Ketelaar (1698) in Dutch will be presented with the intertwining threads of historical, cultural and epistemological contexts. Additionally, the paper will provide an update on the discovery of recently found manuscripts of the oldest grammar by Ketelaar, which not only connect various dots in the discovery of the HindiHindustānī grammatical tradition on one hand but also open new frontiers in the study of the evolution of scientific thought in the linguistic sciences.

\section{The Pioneering Context}

Before turning to the nature of the oldest grammar itself, some remarks are in order about Ketelaar, which will, in turn, explain the rather unusual context that gave birth to the first grammar.

Ketelaar had an interesting life in terms of the array of trading, diplomatic and linguistic journeys he undertook in India and in Arabia. His real family name was Kettler. He was a German, born at Elbing on the Baltic Sea, on 25 December 1659, as the eldest son of a bookbinder. He started his career as a bookbinder's apprentice but often got into trouble, robbing and even trying to poison his master. Fired from his job, he went to Danzig (now Gdansk), where he committed another theft, eventually leaving for Stockholm in 1680. Two years later he joined the East India 
Company and sailed for India and his last name was changed to Ketelaar. Globalization and outsourcing are not a recent phenomenon: it was present in the seventeenth century! The East India Company in those days hired a large number of "its lower personnel from Germany" (Vogel 1935 [1964 reprint]: 817) perhaps due to military and economic ambitions of the East Indian Company, particularly the East India Company's joint collaboration with the Dutch United East India Company to attack Portuguese and Spanish ships off the coast of China in order to secure trading posts in China. On his arrival at Surat in 1683, he was appointed as a "pennist," a clerk. He rose to the position of "assistant" in four years. Between 1705 and 1708 he successfully completed two Arabian missions of purchasing coffee. By 1708 he was appointed as "senior merchant". Because of his expertise in the "Moorish" language and customs he was accredited to the Moghul emperors, Shāh Bahādur Shāh (1708-1712) and Jahāndār Shāh (1712), as Dutch envoy. In 1711, he was also appointed the company's "director of trade" at Surat (see Vogel 1935 [1964 reprint] for more on Ketelaar's biography). The term "Moorish", meant "Muslim" in European languages of the time but in the context of India, Ketelaar and others refer specifically to the Arabic, Persian mixed variety of Hindī-Hindustānī.

As an ambassador of the Dutch Embassy, he accompanied Jahāndār Shāh to Delhi during the summer and rainy season of 1712 to negotiate official firmāns 'an edict, decree or a royal letter'. From the official documents, it is clear that Ketelaar took an active role in diplomatic and business negotiations. On the way to Delhi, he took a short route through Rajasthan. At this time, he had to pay a considerable toll tax, rāhd $\bar{a} r \bar{\imath}$, while passing through the Jat territory of chief Churāman, which became the subject of controversy for his employer. In October, he undertook a return journey to Surat via Agra, Gwalior, Narwar, Sironj, Sarangpur, Ujjain, Dohad, and Godhra. During this journey, he experienced even more troubles, encountering peasant revolts and a run with fearsome tribes such as the Bhils and Kolies. This adventurous trip put him in contact with a wide variety of diverse ethnic groups. Once back at Surat, bad news awaited him. The emperor Jahāndār Shāh was overthrown by his nephew, Farruksiyār. Consequently, he could not reap the benefits of his cumbersome travels and business negotiations.

In 1715, Ketelaar was appointed Dutch envoy to Persia. His mission to Persia mirrors his visit to Delhi: full of adventures and diplomatic activities. On 12 May 1718 he died of fever at Gombroon (now Bandar Abbas) on the Persian Gulf while returning from Isfahan; the fever may have been contracted during a two-day stay in the local jail occasioned by his refusal to order a Dutch ship to act, under the Persian governor's orders, against Arab invaders (see Vogel 1935). Perhaps it was not in the interest of trade policies of the Dutch East India Company to side with Persia against Arabia. 
In relation to his grammar, it is notable that in 1700 Ketelaar was assigned the charge of the Dutch factory at Agra. According to Vogel, in a letter dated 14 May 1700, the Director and Council of Surat sent Ketelaar and his deputy Isaac (Jsaacq) van der Hoeve instructions concerning the management of the factory. From this letter it becomes clear that in addition to Surat and Delhi, Agra and Lucknow also played an important role in Ketelaar's life. In short, Ketelaar developed an in-depth field knowledge of India, Arabia, and Persia by interacting with different strata of the society. He was quite well-versed in the areas of business, diplomacy, and military. He must have been an excellent communicator. In addition to Gujarat, his affiliation with the Hindī-Hindustānī and Rajasthani-speaking areas was quite strong. This explains the distinct nature of the Hindī grammar that Ketelaar wrote. His copyist was none other than his close associate and deputy, which reduced chances of copying errors, but they exist nevertheless.

From Ketelaar's profile, it is clear that the Hindi grammatical tradition is primarily alien in origin: its founders were not natives of India nor did they share the conception of grammar laid down by Indian grammarians. Unlike Sanskrit grammarians, Europeans were not masters of the language whose grammar they attempted to write nor did they prefer to write in Indian languages. During the initial stages, European linguistic attitudes toward Hindī or other Indian languages differed sharply from those of Sanskrit grammarians. For Sanskrit grammarians, Sanskrit was devavāṇ (the voice or language of gods), whereas for the founders of the Hindī grammatical tradition, Hindī was considered moorish (the language of the uncultured). Sanskrit grammars were written to cater to the needs of Indian learners, whereas Hindī grammars were written primarily for a European audience with the aim of teaching them Hindī as a second language. For a considerable period of time, especially during the initial stages of the development of Hindi grammar, activities pertaining to that grammar were carried out by those who were not trained linguists or grammarians. Ketelaar and his successors were diplomats, businessmen, medical surgeons, army officers, civil servants, artists, and missionaries who were driven to the writing of grammars, primarily for utilitarian motives (see Bhatia 1987, p. 67-98 for details about early Hindi grammarians during the Gilchrist Era and their motivations for writing grammars). Some, like Ketelaar, were interested in Hindī entirely for pragmatic and economic considerations; others were interested for intellectual reasons, that is, to provide a description of the language and to fulfill the pedagogical requirements of European learners (for issues pertaining to the deciphering and describing vernacular grammatical tradition of India, see section on 'distorting a grammatical tradition' in Bhatia 1987, p. 46-50 and Bhatia and Machida 2008, p. 21-23). Unlike Sanskrit grammarians, their involvement in grammar writing was not motivated by highly 
theoretical and metalinguistic concerns. Particularly during the formative stages (1698-1770), they did not exhibit any special interest in a classical grammatical tradition let alone in theoretical debates or in the conception of any metalanguage. Their functional and pedagogical interests preoccupied them throughout their linguistic endeavours. Thus in no serious sense is the dawn of grammatical tradition of the Hindī language representative of the tradition handed over to it by Sanskrit grammar. It emerged as an alien tradition in the linguistic scene in India.

Although the Hindi grammatical tradition evolved largely independently of the Sanskrit grammatical tradition, it is worth noting that when Ketelaar was engaged in writing his grammar, a new research paradigm was also emerging, prompted by the 'Age of Discovery'. A multitude of motivations such as the consideration of civilizing the old world (e.g. the spread of Christianity), and trade, and epistemology among others, set the stage for linguistic and cross-cultural endeavors. While Ketelar was in Surat, Gujarat, the presence of Catholic and Jesuit missionaries was quite pronounced in South India (see the Map 1; also see McGregor 2001, p. 9-10 on the Capuchin friar of Surat per se). The explosive issue of Malabar rites-the adaptation of local rituals into Christianity in the Catholic Church-also had its own linguistic dimension, which favored vernacular languages (i.e. HindīHindustānī and other local languages) over prestige languages such as Persian and Sanskrit. Hindī-Hindustānī was, by then, considered the most widely spoken language in the Mughal courts, namely in the court of Akbar (1556-1605) and Jahangir (1605-1727). Hindustani was deemed a critical language for the pursuit of a long-term religious and intellectual exchange between the Jesuits and the Indians. In a Jesuit report of 1649, Francesco Morando was credited as a "great master of Parthian and the Hindī-Hindustānī language" (see Aranha 2015, p. 344 for more details). Although Ketelaar's work was pioneering, it is hard to conceive of the possibility that Ketelaar was totally unaware of such cross-cultural dimensions of Hindī-Hindustānī and the contact between the two classical grammatical traditions, namely Sanskrit and Latin.

\subsection{Search for the Oldest Grammar of Hindi: New Discoveries and Explanations}

Until the 1930's the oldest grammar of Hindi was considered to be extinct. Naturally, then, the authorship, dating and authenticity of the grammar were shrouded in mystery. The discovery of the oldest grammar has its own interesting history. A series of historical accidents and intermittent exchanges of information among a handful of scholars saved the grammar from being extinct. The key researchers who uncovered the first grammar of Hindī are Sir George Grierson, Emilio Teza, 
Professor Suniti Kumar Chatterjī and Dr. J. Ph. Vogel. The period of its search and research can be delineated into five phases.

(1) In April 1893, Sir George Grierson read a paper entitled "On the Early Study of Indian Vernaculars in Europe" at a meeting of the Asiatic Society of Bengal. The abstract of the paper subsequently appeared in the society's journal (Grierson 1893, Part 1, p. 41-50). In this paper Grierson stated that the first grammar of Hindī was that of Benjamin Schultze, written in 1745, which he had not had the opportunity to see.

(2) The second phase began with the reading of a paper by Emilio Teza before the Reale Accademia dei Lincei of Rome in January 1894. The title of this paper was "Dei primi studi sulle lingue industaniche alle note di GA. Grierson," and Grierson published an abstract of it in the proceedings of the Asiatic Society of Bengal (Proceedings of the Asiatic Society of Bengal, May 1895, p. 89-90). By correcting the date of Schultz's grammar as cited by Grierson, Teza rightly pointed out that in his preface Schultz mentioned yet another early grammar-the grammar of Ketelaar, which appeared in Dissertationes Selectae, edited by David Mills in 1743 (Mills 1743, p. 455-488).

At this point in our history, information about the existence of Ketelaar's grammar was based on indirect evidence (its reference in Schultz's grammar); no scholar, including Schultz, claimed to have actually seen it. But Grierson's unveiling of Mills's work first in the proceedings of the Asiatic Society of Bengal (1895) and subsequently in his monumental work, Linguistic Survey of India (Grierson 1916, Vol. IX, Part I, p. 6-8), improved the situation significantly. Mills's work purported to be a translation of Ketelaar's grammar in print. Grierson presented a very brief account of the grammar and hypothesized that it had been written in 1715. Grierson's account of the grammar was very sketchy, only one paragraph in length, and left considerable room for misconceptions.

(3) The first relatively detailed account and analysis of the Hindī grammar appeared in 1933 [written in 1931] with Suniti Kumar Chatterjī's article "The Oldest Grammar of Hindustānī" (1933). The article was written approximately ten years after Chatterjī happened to obtain a copy of David Mills's entire work at a used bookstore in England. This discovery established the existence of Ketelaar's grammar beyond any doubt and removed several misconceptions about it. The article revealed that the original grammar was written in Dutch and was translated into Latin and published by David Mills in 1743. Chatterjī also supported Grierson's dating of the grammar, 1715, and emphasized that the original manuscript of the grammar was lost.

(4) Major credit for setting the record straight about the date and existence of the original grammar goes to a well-known orientalist, Dr. J. Ph. Vogel. In 
response to Chatterjī's article, Vogel wrote him a note in October 1932. The aim of this note was to point out two issues: that the original grammar was written much before 1715, and that the original manuscript was not lost but was still preserved in the Royal Archives of the Netherlands.

Yet Ketelaar's work languished. In 1976 Vechoor translated into Hindi Mills's Latin version of Ketelaar's original. Although Vechoor reported the existence of the original grammar, he made no effort to find out about it.

(5) In July 1981, Bhatia visited various archives in the Netherlands and was able to get a copy of the manuscript of the oldest grammar. Thus, it took approximately a century of scholarship (1893-1981) to establish the dating, authorship, and authenticity of the grammar. However, this scholarship still fell seriously short of establishing the precise nature of the original grammar.

About half a century passed between the time Vogel (1941) brought the original manuscript to the attention of scholars and when Bhatia found a copy of the oldest grammar. Over these fifty years several books, translations, and articles were published on the oldest grammar. Yet prior to Bhatia's attempt to secure Ketelaar's original manuscript, no scholar had responded to Vogel's comment by seeking it out.

At the critical juncture, it is ironic that Mills's Latin translation, which led scholars to the original manuscript, also posed a serious threat to it. It overshadowed the original, and the supposition that it was the oldest version in existence had become a reality in the minds of scholars. The existence of the Latin version seems to have cast a spell on investigators, leading to curious errors and misconceptions. Moreover, Indian as well as Western scholars took it for granted that Mills's translation was an authentic and faithful representation of the original work. It has been analyzed, reanalyzed, and translated as such. An understanding of the true nature of Ketelaar's grammar is finally formulated, after scholarship on the topic has compounded and become entrenched in error upon error. This work is the first attempt to present the first comprehensive study of the grammar, making it possible to evaluate the validity of the claims made by scholars about the grammar in an objective fashion.

As pointed out above, in July 1981, Bhatia visited various archives in the Netherlands including the Utrecht University Library. The only manuscript he found in The Hague, National Archives was then considered "original and only surviving" manuscript (see Bhatia 2008, vol. 1, p. 17 on the discovery of The Hague, National Archives (dated 1698; see Fig. 1)). As it stands now, in addition to The Hague National Archives, two other manuscripts of the oldest grammar exist-the Utrecht University Library (Ms. Number 1478; See Fig. 2) and the Paris Manuscript (Paris, Hôtel Turgot, Fundation Custodia library, Institut Néerlandais, Inv. no. 1991-A615, 183 p.). The discussion of the Paris manuscript 
is outside the scope of this paper since our efforts to obtain its copy have not yet succeeded.

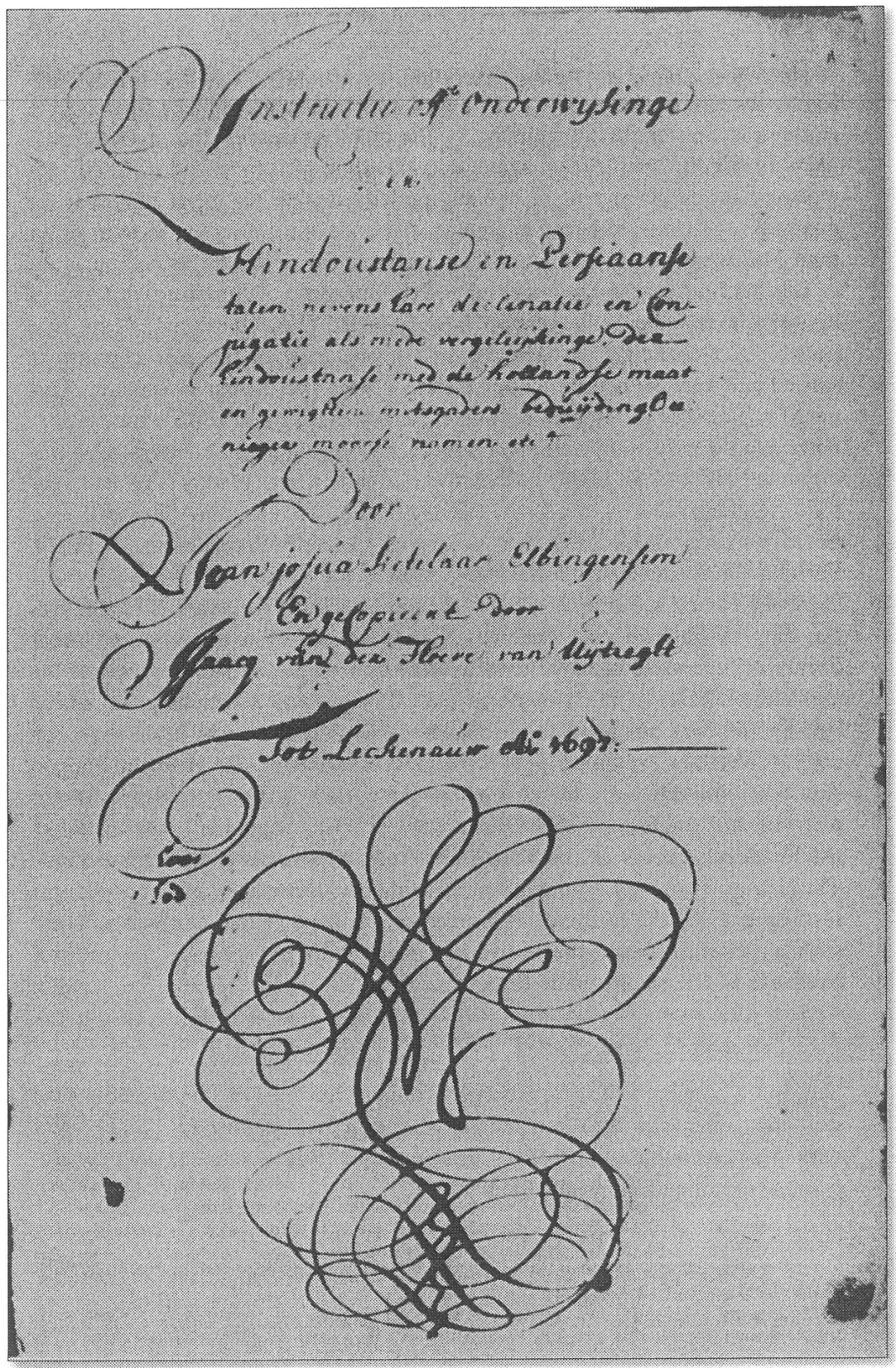

Figure 1. Title Page of The Hague Manuscript: Ketelaar's Grammar (1698) 


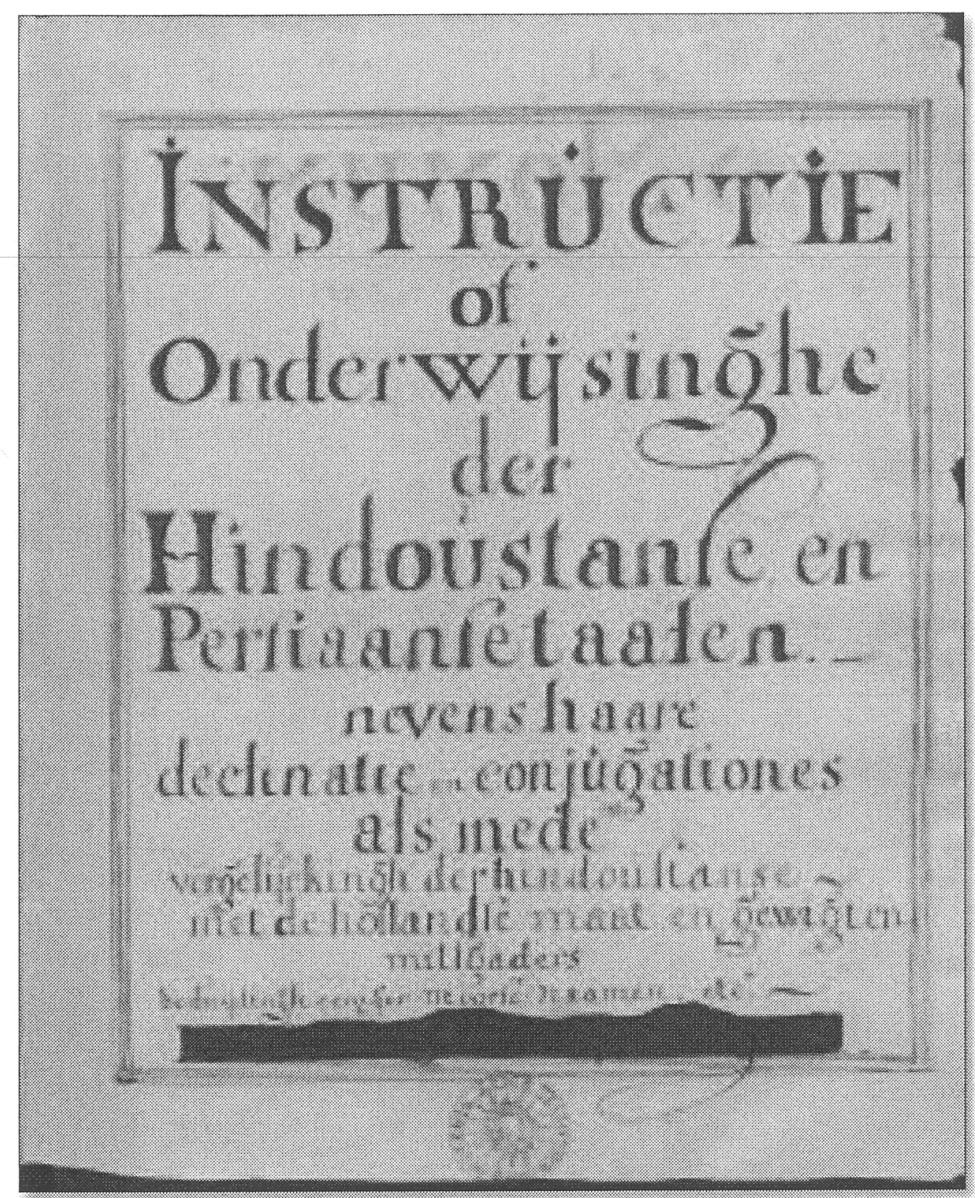

Figure 2. Title Page of The Utrecht Manuscript: Ketelaar's Grammar

The underlying reason why the Utrecht University Library manuscript remained elusive during Bhatia's 1981 search was that the manuscript was undated and the author's identity was deliberately masked with ink, thus concealing it. We hypothesize that the grammar earned a unique distinction due to its importance for learning Hindī-Hindustān̄̄ and became a collectable item for high-ranking officers of the Dutch East India Company in India as well as in Japan in the seventeenth century. It is hard to estimate how many times, and by how many individuals, the copying of the original manuscript continued after it was first copied completely by the copyist Jsaacq van der Hoeve in 1698. McGregor (2001) first referred to the existence of the Utrecht manuscript. He inferred and attributed it to Ketelaar based on its title, reported in the works of Bhatia (1987 and 2001) based on the Hague Manuscript. This adds yet another mystery to the oldest grammar of Hindi. 


\subsection{The Hague and the Utrecht Manuscripts:}

\section{Variation and Commonalities}

Why would someone deliberately disguise the name of the author? Who was the copier? By performing a Quantitative Hyperspectral Analysis in 2011, Anna Pytlowany further reconfirmed Ketelaar as the author. McGregor (2001, p. 20) conjectures that the Utrecht manuscript may have been copied from Ketelaar's original material for private use by someone already having some acquaintance with Hindī-Hindustānī, but less familiar with its vocabulary than its grammar.

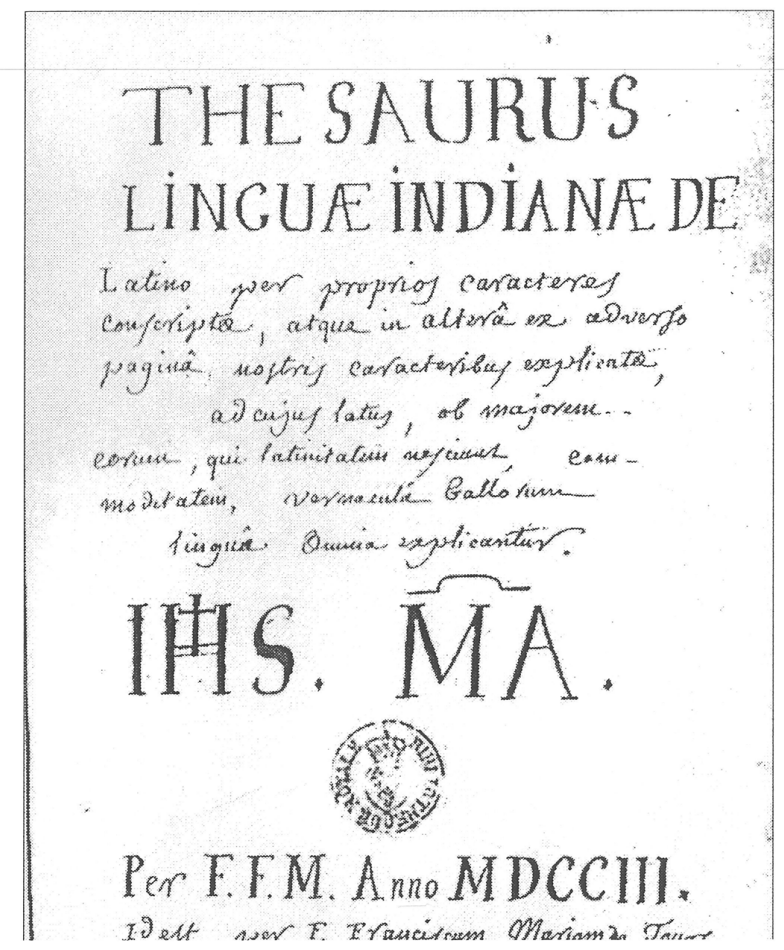

Figure 3. François-Marie de Tours' Thesaurus Linguae Indianae: Title Page Source: McGreor 2001:12

\section{François-Marie de Tours' Thesaurus (1703-MDCCIII) and Grammar (1704)}

It seems that when Ketelaar was writing his grammar, almost his contemporary, the French Capuchin François-Marie de Tours was also engaged in writing the Thesaurus Linguae Indianae (See Fig. 3). Besides the Thesaurus, he also composed a grammar manuscript of the Grammatica Linguce Indiance Vulgaris sive 
Mogolance (1704; Fig. 4). A preliminary analysis of the grammar reveals that there appears to be two competing visions of the description and the representation of the Hindī-Hindustānī language. While Ketelaar employs the Roman script for HindīHindustānī data, de Tours' work is grounded in the Devanagari script. Furthermore, the latter work is written in Latin, thus conforming to the classical European grammatical model. The scope and the depth of the classical Indic (Sanskrit) tradition is too early to assess as the collaborative work on de Tours' grammar is still in progress ${ }^{1}$. Nevertheless, the influence of the Sanskrit tradition is self-evident from the choice of the Devanagari script and references to the 'Brachmanica', e.g., Sanskrit grammatical tradition.

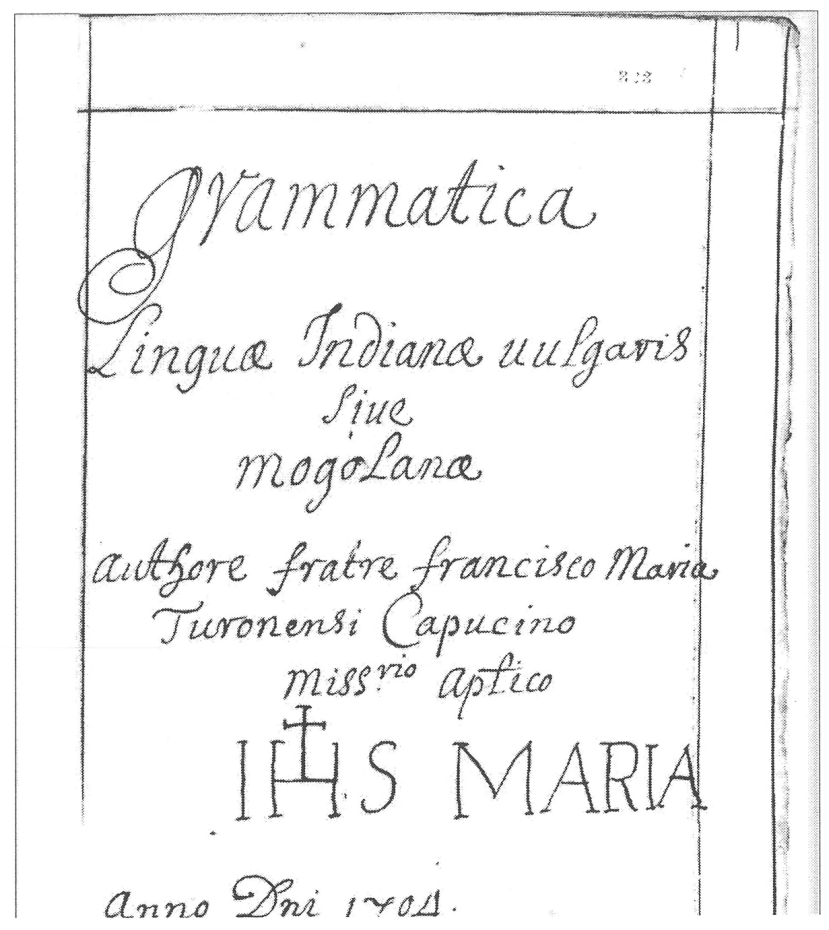

Figure 4. François-Marie de Tours: Grammatica linguœ vulgaris sive Mogolanoe

Let us now turn to an in-depth analysis of Ketelaar's grammar.

1 The collaborative work was initiated by the 2014 Uppsala Workshop (March 5-6) on François-Marie de Tours and the European Discovery of 'Hindi' (Uppsala, Sweden). During the workshop it came to light that de Tours' grammar is still preserved in the Archivio Storico of Congregation for the Propagation of the Faith in Rome. Gunilla Gren-Eklund examined the manuscript during her visit to Rome in March 2011. (See McGregor 2001 and Aranha 2015 for more details). 


\section{The Hague Manuscript [Ketelaar 1698]: An Analysis}

The complete Dutch title of the Hague manuscript and its English translation of Ketelaar's work is as follows.

Instructie off Onderwijsinge Der Hindoustanse en Persiaanse talen, nevens hare declinatie en Conjugatie, als mede vergeleijkinge, der hindoustanse med de hollandse maat en gewighten mitsgaders beduijdingh eenieger moorse namen etc.

\section{Door}

Jean Josua Ketelaar, Elbingensum engecopieert door Jsaacq van der Hoeve, van Uijtreght Tot Leckenauw AD. 1698

Instruction or teaching of the Hindustānī and Persian languages, including their declension and conjugation also comparison of the Hindustānī with the Dutch measure and weights and the meaning of some Moorish names etc.

By

Jean Josua Ketelaar of Elbing Copied by Jsaacq van der Hoeve, of Utrecht at Lucknow A.D. 1698

A complete table of contents of the Hague manuscript is presented below in Table 1 below.

\section{TABLE 1}

A Complete Table of Contents based on the main body of the Hague Manuscript

\begin{tabular}{|c|c|c|c|}
\hline $\begin{array}{l}\text { KeTELAAR's } \\
\text { SECTION }\end{array}$ & Dutch & $\begin{array}{l}\text { ENGLish TRansLation } \\
\text { (By T.K. BHatia) }\end{array}$ & $\begin{array}{l}\text { MANUSCRIPT } \\
\text { PAGES }\end{array}$ \\
\hline$*[\mathrm{~A}]$ & & untitled ("mystery") page & \\
\hline$*[\mathrm{~B}]$ & instructie off ..... & instruction or... & \\
\hline$*[\mathrm{C}]$ & Ad Lectorem Benevolum & to the kind reader & \\
\hline$*[\mathrm{D}]$ & voor Reeden & preface & \\
\hline$*[\mathrm{E}]$ & Register der Capitulen & Table of Contents & \\
\hline 1 & van God & of God & 1 \\
\hline 2 & van de wereld & of the world & 1 \\
\hline 3 & van de lughts vertoogen & of the air & 1 \\
\hline 4 & van de winden & of the winds & 1 \\
\hline 5 & van de gewesten der wereld & of the parts of the world & 2 \\
\hline 6 & van de mensch en sijn deelen & $\begin{array}{l}\text { of the human and his body } \\
\text { parts }\end{array}$ & $2-4$ \\
\hline 7 & van de elementen ${ }^{(\mathrm{a})}$ & of the element & $4-6$ \\
\hline$[7 \mathrm{a}]$ & van de familien & of the family & \\
\hline 8 & van de hooge ampten & of the high offices & $6-8$ \\
\hline 9 & $\begin{array}{l}\text { van de kunst } \\
\text { ambaght en kleine ampten }\end{array}$ & $\begin{array}{l}\text { of the arts and lower } \\
\text { occupations }\end{array}$ & $8-10$ \\
\hline 10 & van de militairen & of the military offices & $10-11$ \\
\hline
\end{tabular}




\begin{tabular}{|c|c|c|c|}
\hline 11 & van verscheijde natien & of the different nations & $11-12$ \\
\hline 12 & $\begin{array}{l}\text { van de veraghte en } \\
\text { oneerlijke ampten }\end{array}$ & $\begin{array}{l}\text { of the despised and } \\
\text { dishonorable occupations }\end{array}$ & $12-13$ \\
\hline 13 & van viervoetige land gediertens & of the quadruped land animals & $13-14$ \\
\hline 14 & van’t gevogelte & of the birds & $14-15$ \\
\hline 15 & van de bloeijeloose beeskens & of the bloodless creatures & $15-16$ \\
\hline 16 & van de feneijnige gediertens & of the poisonous animals & 16 \\
\hline 17 & van de vischen & of the fish & $16-17$ \\
\hline 18 & van de eetwaaren & of the foods & $17-18$ \\
\hline 19 & van de drank & of the beverages & $18-19$ \\
\hline 20 & van de kleeden & of the clothes & $19-20$ \\
\hline [21] & van't huijen sijn deelen & of the house and its parts & $20-21$ \\
\hline 22 & van't huijsraed en reetschappen & of the furniture and tools & $21-26$ \\
\hline 23 & van de oorlogs behoeften & of the war materials & $27-28$ \\
\hline 24 & $\begin{array}{l}\text { van den boomen ende sijn } \\
\text { vrughten }\end{array}$ & of the trees and their fruits & $28-29$ \\
\hline [25] & $\begin{array}{l}\text { van de thuijn en veld } \\
\text { vrughten }^{(b)}\end{array}$ & $\begin{array}{l}\text { of the garden and field fruits } \\
\text { [crops] }\end{array}$ & $28-29$ \\
\hline 26 & van de specereijen & of the spices & $29-30$ \\
\hline 27 & van de juweelen & of the jewels & 30 \\
\hline 28 & van de bergiften & of the minerals & 31 \\
\hline 29 & van’t geld & of the money & $31-32$ \\
\hline 30 & van de landschappen & of the landscapes & $32-33$ \\
\hline 31 & van't schip en toebehooren & of the ship and its equipment & $33-34$ \\
\hline 32 & van de verruwen & of the colors & $34-35$ \\
\hline 33 & van de tijden & of the times & $35-36$ \\
\hline 34 & van de maanden & of the months & 36 \\
\hline 35 & van de dagen & of the days & 37 \\
\hline 36 & van't getal & of the numbers & $37-38$ \\
\hline 37 & van't order getal & of the ordinal numbers & $38-39$ \\
\hline 38 & van't gebrooken getal & of the fractional numbers & 40 \\
\hline 39 & van de vijv sinnen & of the five senses & 40 \\
\hline 40 & van verscheijde siecktens & of different illnesses & 41 \\
\hline 41 & van verscheijde oliteijten & of different oils & 41 \\
\hline 42 & $\begin{array}{l}\text { van devirse substantiva ende } \\
\text { adjectiva }\end{array}$ & of diverse nouns and adjectives & $42-52$ \\
\hline 43 & van de adverbia & of adverbs & $52-56$ \\
\hline 44 & verba & verbs & $57-66$ \\
\hline [45] & verba der eerste conjugatie & verbs of the first conjugation & $66-71$ \\
\hline 46 & $\begin{array}{l}\text { van de declinatie der Persiaanse } \\
\text { taale }\end{array}$ & $\begin{array}{l}\text { of the declension of the Persian } \\
\text { language }\end{array}$ & $72-73$ \\
\hline
\end{tabular}




\begin{tabular}{|c|c|c|c|}
\hline 47 & $\begin{array}{l}\text { van de conjugatie der } \\
\text { Persiaanse }^{(c)} \text { taale }\end{array}$ & $\begin{array}{l}\text { of the conjugation of the } \\
\text { Persian language }\end{array}$ & $74-78$ \\
\hline$[48]$ & $\begin{array}{l}\text { declinatie der } \\
\text { Hindoustanse }^{(\mathrm{d})} \text { taale }\end{array}$ & $\begin{array}{l}\text { declension of the Hindustānī } \\
\text { language }\end{array}$ & $79-85$ \\
\hline 49 & $\begin{array}{l}\text { conjugatie der Hindoustanse }{ }^{(\mathrm{e})} \\
\text { taale }\end{array}$ & $\begin{array}{l}\text { conjugation of the Hindustāni } \\
\text { language }\end{array}$ & $86-92$ \\
\hline 50 & $\begin{array}{l}\text { beduijding eeniger Moorse } \\
\text { namen }\end{array}$ & $\begin{array}{l}\text { meaning of some Moorish } \\
\text { names }\end{array}$ & 93-94 \\
\hline 51 & naast gelijckende woorden & $\begin{array}{l}\text { homonymous and semi- } \\
\text { homophonous words }\end{array}$ & $94-97$ \\
\hline 52 & $\begin{array}{l}\text { explicatie van verscheijde soo } \\
\text { persiaans als Hindoustanse } \\
\text { woorden bij mooren } \\
\text { gebruijkelijk }\end{array}$ & $\begin{array}{l}\text { explanation of several Persian } \\
\text { and Hindustānī words used by } \\
\text { the Moors }\end{array}$ & $\begin{array}{l}98-106 \\
{[106-107} \\
\text { blank }]\end{array}$ \\
\hline [53] & $\begin{array}{l}\text { Tien Giboden; de twaelf } \\
\text { artijkulen onses algemeenen } \\
\text { endo ongetwij feld en christal } \\
\text { geloofd; } \\
\text { Tonse Vader }{ }^{(f)}\end{array}$ & $\begin{array}{l}\text { Lord's Prayer; The Twelve } \\
\text { Christian Beliefs; Our Father }\end{array}$ & $\begin{array}{l}108-111 \\
{[112-117} \\
\text { blank }]\end{array}$ \\
\hline [54] & $\begin{array}{l}\text { instructie tot gebruijck der } \\
\text { volgende taefel(g) }\end{array}$ & $\begin{array}{l}\text { instruction to the use of } \\
\text { following table }\end{array}$ & $118-123$ \\
\hline [55] & index... & index... & $124-144$ \\
\hline
\end{tabular}

[ ] our insertion or numbering; sections [A], [B], [C], [D], [E] are not included in Ketelaar's Register der Capitulen (Table of Contents).

(a) Although Ketelaar's table of contents give the following title "van de gewesten der wereld en elementen," the element portion is actually covered in section 7 of the main body.

(b) Section 25 "van de thuijn en veld vrughten" 'of the garden and its field fruits [crops]' of Ketelaar's table of contents is merged into section 24.

(c) Ketelaar's table of contents: 'Moorse' instead of "Persiaanse"

(d) Ketelaar's table of contents: "Moorse' instead of "Hindoustanse"

(e) Ketelaar's table of contents: "reductie van caren en ponden" 'deduction of caren and pounds' in stead of "Tein Giboden..."

(f) Ketelaar's table of contents lack the title: "explicatie van verscheijde soo persiaans als Hindoustanse woorden bij mooren gebruijkelijk"

(g) Ketelaar's table of contents the title: "index..."

A comparison of the Hague and the Utrecht manuscript reveals the former is a longer version. The Utrecht manuscript represents a slightly abbreviated version of the Hague manuscript. It has fifty-two chapters; chapter 41 of the Hague manuscript on oils is missing. Also, the section on Lord's prayers is not included. However, it includes a poem by the author. The copyist is unknown. The manuscript is written partly in Gothic script and seems not have been produced with quite "the same motivation and purpose, as the Hague manuscript" (McGregor 2001, p. 20). The Hindi and Persian data representation follows the same pattern witnessed in the Hague manuscript. In other words, Hindustani and Persian data are both in the Roman script.

Ketelaar's grammar has the general organization of: the title page, a foreword by the copyist (Ad Lectorem Benevolum "to the kind reader"), a brief introduction 
to the Hindī language by Ketelaar (voor Reeden "Preface"), a table of contents, the main body of the work consisting of two components-lexicon and grammar-followed by a Hindī translation of some Christian texts. It ends with an index of Dutch words with page numbers indicating where the Hindi//Persian words are in the text.

In his introduction Ketelaar remarks primarily on three main points: the multilingual setting of seventeenth-century India, varieties of Hindī and its writing systems, and the problems of representing the correct Hindi pronunciation in Dutch letters. Related to the varieties of Hindī and its writing systems, he mentions the existence of geographical and ethnic varieties of Hindī and stresses the wideranging impact of Persian on Hindī. As evidence of the Persian impact Ketelaar points out that although Hindī can be written in native scripts, it is a common practice to write it in Persian letters. In regard to the variety of Hindī under investigation in his work, he remarks that his target is "the spoken variety". The treatment of these two points is sketchy but objective and accurate in nature.

Interestingly, in the foreword to the grammar the copyist abandons his traditional role of commenting on the text and its author. Instead, Jsaacq van der Hoeve chooses to highlight the underlying motivations for learning a foreign language. His observations provide further insights into the attitudes of seventeenth-century Europeans toward learning a second language (see for details Salmon 1985; Lambley 1920). Mobility and intellectual gains are cited as two important motivations. His observations have not at all lost their validity or freshness with the passage of more than three centuries.

The table of contents of Ketelaar's grammar reveals other key goals-pragmatic (e.g. commercial, military, among others) and religious goals-that were left unaccounted for by Jsaacq van der Hoeve. Whether the pragmatic and religious objectives reflect the personal identity of Ketelaar or the language policies of the Dutch East India Company requires further research.

Recall that the main body of the work consists of two components-a lexicon and a grammar. The grammar component is sandwiched between the two main parts of the lexicon. The first portion of the lexicon (Ketelaar's sections 1-44) constitutes nearly half of the work and is organized into forty-one semantic and three grammatical classes. The second part of the lexical component (sections 50-52) is devoted to teaching the meaning of "Moorish" names, of phonetically similar words or expressions (homonyms and near homonyms), and of culturally sensitive Hindustānī words. An alphabetic index is provided at the end of the grammar.

An attested lexicographic tradition, in the form of both monolingual and bilingual dictionaries, can be traced back to Latin and Greek in Europe dating back to, at least, the period up to 6th century AD. The main object of such dictionaries was to immerse second language learners in Latin and Greek on one hand and to 
provide translational tools to scholars and traders (Dionisotti 1988). India has its own attested Sanskrit tradition of thesauri and dictionary endeavors as evidenced by Amarakośa written by scholar Amarasimha (dating back to approximately 4th7th century AD) ${ }^{2}$. Interestingly, the first part of Amarakośa 'immortal treasure' contains the names of gods and aspects of the heavens among other entities. Turning to the European tradition, the work of J. A. Comenius's Latin Reader, Janua Linguarum reserata $(1629 / 1631)$ is worth mentioning. In the Latin Reader the contents (vocabulary) are ordered according to the world of the Bible-first its creator, then other things follow in the order of their creation (see Bhatia 1987, p. 33 for details). To what extent Ketelaar's organizational and sequential schema in terms of semantic sets was the result of the broad lexicographic tradition of Europe (and/ or India) and to what extent was it his own innovation is unknown at present? To what extent is it influenced by the later Indic tradition? For instance, a 16th-century document, Ain-i-Akbari or the 'Constitution of Akbar', which presents an administrative account of the Akbar's empire, contains military, money and administrative terms among others ${ }^{3}$. These questions remain to be answered and are the subject of independent future research. Nevertheless, it cannot be ruled out that perhaps Ketelaar's chosen semantic organization and sequencing was not a pioneering schema in its entirety; it may well have been influenced by the long lexicographic tradition of Europe and/or India spanning back to middle ages. See Herren and Brown 1988; Osselton 1973 on the earliest English and Dutch dictionaries among others. In spite of the possibility of manifold influence, it is worth noting that his lexical schema was unique in the history of the Hindi grammatical and lexicographic tradition since no subsequent grammar-particularly, grammars written by Europeans-emulate his pattern.

Between the two portions of lexicon we find a grammatical sketch of Persian (sections 46-47) and of the Hindustāni language (sections 48-49). Only seven pages of the grammar section are devoted to Persian. Hindustānī grammar is dealt with in eleven pages. It should be pointed out that sections (42-44) of the lexicon, however, are motivated by consideration of the grammar (e.g. capturing formal generalization by rule formulation).

Three noteworthy properties of the work emerge at first glance. First, it is primarily data-oriented. Contrary to the underlying generic nature of Indic language grammars, it places heavy emphasis on presenting raw Hindi data (e.g., nominal, verbal paradigms etc.) rather than on formulating rules and capturing generalizations based on the presented data. Rule formulation is not lacking though. In the verbal and nominal paradigms and morphology, the data-oriented 
approach begins to yield rule formulation. He attempts to capture and present syntactic and morphological generalizations under the heading "Rule". Second, the grammar is developed in the lexicographic tradition. More emphasis is given to the dictionary of Hindī than to the grammatical sketch of the language. This property distinguishes it from both the preceding Indian grammatical tradition and the succeeding Hindī one, in which lexicography was seen as an independent component of language pedagogy and was rarely mingled with the grammatical component. Two notable exceptions in Hindī were George Hadley (Grammatical Remarks on the Practical and Vulgar Dialect of Indostan Language, 1772) and William Yates (Introduction to the Hindustani Language in Three Parts, 1827). The third notable feature of Ketelaar's work is its bilingual approach, which surfaces in both the grammatical and the lexical components. The grammar was intended as a two-language grammar, that is, of Hindī and Persian, an attempt to write a conjoined two-language grammar. Perhaps the dual grammar attempt was motivated by the similarity between the two languages and Ketelaar's interest in comparative methods. Similarly, Ketelaar attempted to provide a bilingual lexicon by presenting Persian equivalents of the Hindī lexical items but, unfortunately, could not complete the Persian section; a significant portion of it was left blank. Nevertheless, this approach can be very rewarding since it can provide to researchers an empirical basis for distinguishing between Hindī and Persian. Consider, for example, Ketelaar's listing of Persian and Hindī words for 'snow'. He assigns the word baraf to Persian but not to Hindī. Surprisingly, the Persian word is an integral part of modern-day Hindīi ${ }^{4}$

Other distinctive characteristics of the work emerge when one glances through the dictionary section. A set of three criteria went into his overall classification of lexicon-semantics, grammar, and acquisition. Ketelaar divided the Hindī lexicon into forty-one semantic (sections 1-41), three grammatical (42-44), and three pedagogically-motivated (51-53) classes (see Table 1 for Ketelaar's terminology). Although some of the semantic classes, such as the family, numerals, names of days, months, and humans and parts of the body, overlap with those in traditional grammars, most of them fall in the domain of grammars for "special purposes". The inclusion of classes of vocabulary dealing with high offices, despised and dishonest professions, military offices, jewels, money, ship and its equipment, and the like must have been inspired by, but not restricted to, the European and

4 For details on the empirical basis of language differentiation in the area of bilingual language mixing within the generative framework, see MacSwan (2006). According to MacSwan's theoretical account of Code/Language Switching within Chomsky's Minimalist Program, there is no room for a mechanism specific (or 'third grammar' constraints) to Code Switching; Code Switching can best be characterized by independently motivated principles of grammar which are shared by monolingual as well as bilingual grammar. 
lexicographic and phrase book tradition as evidenced in the merchant and marine dictionary of Berlaimont and others. Nevertheless, special purpose grammars involving professional lexicon mark a point of departure from the usual trend in the development of the grammatical tradition of a language, since they are generally viewed as late developments in such traditions. Lexicon is the main strength and salient feature of his work. The merit of this approach is valid not only for language learning and communication but also for linguistic theory and the theory of language and consciousness. Lexicon is the main strength and salient feature of his work. ${ }^{5}$

Ketelaar places more emphasis on communicative competence than on grammatical competence. His communicative approach is grounded in culture-based language teaching (see Ritchie and Bhatia 1996 and 2009 for details). This approach is self-evident from his rather detailed treatment of "Moorish" names and similar (homophonous or semi-homophonous) words, and his definition/explanation of culture-specific words given in sections (50-52) of his work. Even the title of his work emphasizes the pragmatic and pedagogical aspects of his work.

\section{Ketelaar's Grammar and Contributions to Comparative-Historical Methods}

The grammar is not free of shortcomings. The most serious is that Ketelaar failed to distinguish among tenses (present, perfect, and future), moods (imperative, etc.), and participles (imperfect, etc.). Also, it seems that variations and exceptions motivate his subclassification of perfect and future tense. He was a structuralist in his orientation: he had neither a conceptual sociolinguistic framework nor the analytical tools to analyze free variation. For every distinct form encountered, he posited a subcategory of the tense. A case in point is his classification of first future and second future. For a detailed analysis of Ketelaar's grammar section, see Bhatia and Machida 2008, p. 40-42. In spite of these weaknesses, one must give credit to Ketelaar that he never failed in his observation about the SOV word order of Hindi. Also, one must remember that it was not written in a prescriptive framework. Prescriptive grammarians may decry his errors, but they are a gold mine for researchers in (real-time-) language processing, second-language acquisition, sociolinguistics, language variation, language methodology, and language modeling, particularly for linguistic ecology and language evolution (see Mufwene 2001).

5 For comparative and contrastive purposes, it is worth pointing out that lexicon has gained a central position in Chomsky's linguistic theory, the Minimalist Program to generate syntactic trees. In this program, there are two central components of syntax $-\mathrm{C}_{\mathrm{HL}}$, a computational system for human languages that is invariant across human languages, and a lexicon that is variable in the sense that it is responsible for language-specific variation across human languages. All parameters are coded in the lexicon (see Chomsky 1995 and 2001 for details). 


\subsection{Seeds of Comparative-Historical Methods}

Ketelaar ends his section on Persian grammar with the presentation of the two comparative lists (Ketelaar manuscript page 78). In the first list Persian, Latin and Dutch cognates/similar words are presented (Table 2) while the second list comprises of Persian-Dutch similar words (Table 3) below.

\section{TABLE 2}

(Basic) Vocabulary: Persian, Latin and Dutch

\begin{tabular}{l|l|l|l} 
Persiaens [Persian] & Latisns [Latin] & DuiJTs [DutCH] & EnGLish \\
\hline pader & pater & vader & father \\
\hline mader & mater & moeder & mother \\
\hline musch & mus & muijs & mouse \\
\hline dend & dans & tant & tooth \\
\hline kalo & calamus & penne & pen \\
\hline na & ne & neen & no \\
\hline jongl & jugum & jo & yoke \\
\hline tu & tu & ghij & you \\
\hline du & dua & twee & two \\
\hline no & novem & negen & bow \\
\hline de & decem & tien & ten \\
\hline pare & pars & deel & part
\end{tabular}

TABLE 3

(Basic) Vocabulary: Persian and Dutch

\begin{tabular}{l|l|l} 
PERSIAN & DuTCH & ENGLISH \\
\hline brader & broeder & brother \\
\hline dogter & dogter & daughter \\
\hline berber & barbier & barber \\
\hline lep & lip & lip \\
\hline kal & kaal & bald \\
\hline storgh & ster & star \\
\hline nahm & naem & name \\
\hline nou & nieuw & new \\
\hline bend & band & tie
\end{tabular}


Long before the suggestion of the genetic relationship between Greek, Latin and Sanskrit by Sir William Jones, the German-Persian comparative vocabulary approach was generating a great deal of enthusiasm, see Muller (1986). Ketelaar either intuitively or due to his familiarity with the Persian-German approach succeeded in sowing the seeds of comparative-historical methods. Ketelaar's lists provide a rare treat of the pre-scientific era of the nineteenth century revolution. It is difficult to assess the impact of the Ketelaar's grammar on the development of comparative linguistics though, as it was unpublished. Whether or not Sir Jones had access to Ketelaar's work and/or its Latin translation by Mills, it is the subject of future research.

\section{Applied Linguistics and Second Language Learning}

The importance of Ketelaar's manuscript goes far beyond its mere existence. It now has a unique place in the grammatical tradition of Hindī and fills gap in our knowledge of Hindī prevalent in the 17th century by being the only work on the 17th century Hindi. It provides a major research tool for researchers of linguistics and of Indic languages.

For historical and applied linguists, it provides access to rare samples of spoken Hindī of the late seventeenth century. Hindī literature fails as a reliable indicator of the actual pronunciation because it is written in the Devanāgarī script, a syllabic writing system. Since Ketelaar employs Roman transcription for his Hindī data, his work preserves important information about the phonetics and phonology of 17th-century spoken Hindī and Persian. His data confirm the presence of the wordmedial as well as word-final schwa syncope rule in the 17th century. Hence, this is not a recent development. The symbol '/' superimposed on the vowel $a$ marks the deletion of schwa in our transcription of Ketelaar's and modern Hindī data in our corpus. For example सेव 'apple' is written in Devanagari as seva but is pronounced as seva (without schwa word-finally). See Bhatia and Kenstowicz (1972), Ohala (1972), Narasimhan, Sproat and Kiraz. (2004) for detailed discussion of schwa syncope rule. Additionally, it provides keen insights into language variation and language contact in the seventeenth century.

Ketelaar's grammar also provides further insights into 17th-century methods of teaching foreign languages. A comparison of the oldest Hindī grammar with succeeding grammars shows a significant shift in content after Ketelaar. No Hindi grammar since his has provided special lists of jewels, dangerous animals, oils, tropical illnesses, military needs, weather elements, and religious terms.

Moreover, modern grammars place much more importance on grammar itself than did Ketelaar's and reflect a significant shift from the pedagogical perspective of the pioneer grammarian. Ketelaar's perspective on the teaching of Hindī 
as a foreign language was essentially religious-colonial-commercial, which was the direct consequence of his and his audience's religious and colonial outlook. The selection of Hindī data is also reflective of nonlinguistic attitudes to some extent. Ketelaar's grammar is rich in expressions of the following types: masterslave relationship (e.g., tom meera gaulam he 'you are my slave'; mai sahab he 'I am a master'; tuu cakar he 'you are a servant'); admission of guilt and deception (daga dijia '(I) deceived'; sac bol 'speak a truth'; etc.); expressions of prayer (nimaz karre 'read Nimaz'); demeaning words for natives, while iisaa 'Christ' meant 'happiness'). The choice and richness of derogatory data suggest the author's colonialist attitude (for details on the models of early Hindi grammar, see Bhatia 2001, p. 99-102 and Bhatia 1987).

Ketelaar, however, saw knowledge of Hindī as a tool to promote commerce in India. His aim was not to teach literacy in Hindī but to satisfy the needs of a narrowly defined group that was interested in carrying out commercial, missionary, and colonial activities in India.

What form of Hindustān̄i-Hindī-Urdū did Ketelaar aimed to analyze and present? Chatterjīi (1933, p. 78) claims Ketelaar did not describe the standard Hindustānī language. Rather, his account was based on the lingua franca spoken from Lahore, Delhi, and Agra to Surat. Chatterjī terms it "bāzār Hindī." Based on our examination of the verbal and nominal paradigms, we are in agreement with Chatterjī's claim. However, as pointed out earlier, lexicon is a key to Ketelaar's work, and in that area he certainly shows in-depth familiarity with High Hindustānī. In this sense, his lexicon exhibits diglossic characteristics-high Hindustānī with PersoArabic words and Low Hindustānī very colloquial. In short, Ketelaar's work shows a complex mix of features ranging from bāzār Hindī to High Hindī, directly resulting from his socialization pattern. Mixtures from Gujarati, Punjabi, Persian, and Arabic renders a colorful mosaic to Ketelaar's Hindī-a mixed variety in action!

In spite of the mixed lexicon, Ketelaar's forms are primarily $k^{h}$ ari $\bar{l}$ boli Hindī, the dialect of Delhi. It is remarkable that he may have problems with verbal or nominal endings, however when we clip endings, resultant forms are $k^{h}$ ari $\bar{l}$ boli nominal and verbal forms. It is remarkable that his $k^{h}$ ari $\bar{l}$ boli forms can be found in modern Hindī dictionaries; Avadh̄̄ and Braj Bhāshā were the dialects in which Hindi literature developed (1375 to $1700 \mathrm{AD}$ ). The first reliable $k^{h}$ ari $\bar{l}$ bolì prose became available later in the 18th century (for more details, see Bhatia 1987).

\section{CONCLUSION}

New discoveries-including those of Francois-Marie de Tours and the French manuscript of Ketelaar's grammars in addition to the Hague and the Utrecht manuscripts-open new frontiers in research on the evaluation of scientific thought in the 
language sciences in general and the impact of Dutch contributions to the Hindi/ Indic grammatical tradition in particular.

Ketelaar's work is representative of the Dutch contributions to the early Hindi grammars and its contributions to language study are manifold. It turns out that the early vernacular grammatical tradition, as represented in Ketelaar's work, is alien in origin which marks a point of departure from the Sanskrit grammatical tradition. Even though the Europeans, perhaps even Ketelaar, were not total strangers to the 'Brahmanic' or scholarly grammatical tradition of India as evidenced by François-Marie de Tours' grammar of Hindi, 1704. See in particular the preface by de Tours to the Dictionary of the Indian or Moghulian Language (1704). Ketelaar's considerable data tend to be nonprescriptive in nature. Variation in the Hindi data is one of its striking features. Except for borrowing categories from classical (Greco-Latin) grammars (e.g. Nouns, Verbs, Adjectives and Adverbs), it does not follow their model. Ketelaar's grammar does not exhibit any preference for standard or prestigious Hindī forms nor does it hesitate to present a tentative analysis of the language at several points. It follows a model which can best be characterized as a Religious-Colonial-Commercial model. It is worth pointing out that Ketelaar was a devout Christian who sent a large sum of money to the Protestant churches in his home town of Elbing (see Vogel 1935). His grammar is to a great extent a by-product of his own world view, as evident from his biographical account. Additionally, the influence of a broad and hybrid lexicographic traditions of the Middle ages on Ketelaar's dictionary arrangement can not be ruled out. Ketelaar's grammar was not descriptive-prescriptive in nature. It was not aimed at a general classroom audience. It was meant for second language learners with pragmatic goals in mind. Ketelaar's grammar provided a new window into the pre-scientific era of the 19th century revolution in Comparative and Historical methods (Pedersen 1967; Trask 1996).

\section{ACKNOWLEDGEMENT}

This work is an extension of Bhatia and Machida (2008) made possible by the funding received from The Japan Science Foundation, The Ministry of Education of Japan and Tokyo University of Foreign Studies.

We are grateful to Professors Pascale Feuerhahn, Matthieu Herman van der Meer and Hans Hock for their comments and suggestions on the earlier version of the paper. This article is also benefitted by the remarks of two anonymous reviewers. 


\section{REFERENCES}

Aranha, Paolo, 2015. "Vulgaris seu Universalis: Early Modern Missionary Representations of an Indian Cosmopolitan Space", Cosmopolitismes en Asie du Sud: Sources, itinéraires, langues (XVI ${ }^{e}$-XVII siècles), eds. Corinne Lefèvre, Ines G. Županov, Jorge Flores, Collection Purușārtha 33, Paris, Éditions de l'École des Hautes Études en Sciences Sociales, 331-360.

Bhatia, Tej K., 1987. A History of the Hindī grammatical tradition: Hindī-Hindustānī Grammar, Grammarians, History and Problems, Leiden, E. J. Brill.

- 2001. "Grammatical traditions in contact: The case of India", Indigenous grammar across cultures, ed. by Hannes Kniffka, New York, Peter Lang, 89-115.

— \& Michael Kenstowicz, 1972. "Nasalization in Hindi: A reconsideration", Papers in linguistics 5:2, 202-212.

Bhatia, Tej K. \& K. Machida, 2008. The Oldest [European] Grammar of Hindustani: Language, Contact and Colonial Legacy, Tokyo, Japan (3 volumes), Tokyo, Tokyo University.

Comenius, J. A., 1662. Janua Linguarum Reserata. Second edition published from Danzig (Gdansk) in 1631.

Chatterjī, Suniti Kumār, 1978. "The oldest classics of the Maithili language - a linguistic study". Selected Writings I, New Delhi, Vikas Publishing House, 177-236.

- 1963. Bhāratiya ārya bhāshāen aur Hind̄̄ [Indian Aryan Languages and Hind̄̄], Delhi, Rajkamal Prakashan.

— 1933. "The oldest grammar of Hindustān̄̄", Indian Linguistics [1965 Reprint] II, 68-83.

Chomsky, Noam, 1995. The Minimalist Program, Cambridge, MIT Press.

- 2001. "Derivation by phase". A Life in Language, ed. by Micheal Kenstowicz and Ken Hale, Cambridge, MIT Press, 1-51.

Dionisotti, Anna Carlotta, 1988. "Greek Grammars and Dictionaries in Carolingian Europe", Herren, M. W. and Brown, S. A. (eds.), The Sacred Nectar of the Greeks: The Study of Greek in the West in the Early Middle Ages, London, King's College Medieval Studies 2, 1-56.

Grierson, George Abraham, 1916. Linguistic Survey of India vol. IX, Calcutta, Office of the Superintendent of Government Printing.

Herren M. W \& S. A. Brown, 1988. The Sacred Nectar of the Greeks: The Study of Greek in the West in the Early Middle Ages, London, University of London King's College.

Hadley, George, 1772. Grammatical Remarks on the Practical and Vulgar Dialect of Indostan Language, Menston, The Scholar Press.

Ketelaar, Jean Josua, 1698. Instructie off Onderwijsinge Der Hindoustanse en Persiaanse talen, nevens hare declinatie en Conjugatie, als mede vergeleijkinge, der hindoustanse med de hollandse maat en gewighten mitsgaders beduijdingh eenieger moorse namen etc. Leckenauw. [Instruction or teaching of the Hindustānī and Persian languages, including their declension and conjugation also comparison of the Hindustānī with the Dutch measure and weights and the meaning of some Moorish names etc. By Jean Josua Ketelaar of Elbing Copied by Jsaacq van der Hoeve, of Utrecht at Lucknow AD 1698].

Lambley, Kathleen, 1920. The teaching and cultivation of the French language in England during Tudor and Stuart times, New York, Longmans, Green \& Co.

MacSwan, Jeff, 2006. "Code switching and grammatical theory", The Handbook of Bilingualism, ed. by Tej. K. Bhatia \& William C. Ritchie, Oxford, Blackwell, 283-311.

McGregor, S., 2001. "The formation of modern Hindi as demonstrated in early 'Hindi' dictionaries", Amsterdam, Royal Netherlands Academy of Arts and Sciences, 1-31.

Mufwene, Salikoko S., 2001. The Ecology of Language Evolution, Cambridge, Cambridge University Press.

Muller, Jean-Claude, 1986. "Early stages of language comparison from Sassetti to Sir William Jones (1786)", KRATYLOS 31, 1-31. 
Narasimhan, Bhuvana, Richard Sproat \& George Kiraz, 2004. "Schwa-deletion in Hindī text-to-speech synthesis", International Journal of Speech Technology 7:4, 391-333.

Ohala, Manjari, 1972. Topics in Hindī-Urdū Phonology, Ph. D dissertation, Los Angeles, UCLA, 202-207.

Osselton, N. E., 1973. The Dumb Linguists: A study of the earliest English and Dutch dictionaries, Leiden, Publications of the Sir Thomas Browne Institute, Special series.

Pedersen, Holger, 1967. The Discovery of Language: Linguistic Science in the 19th Century, Bloomington, Indiana University Press.

Ritchie, William C \& Tej K. Bhatia, 1996. Handook of Second Language Acquisition, San Diego, Academic Press.

- 2009. A New Handbook of Second Language Acquisition, Oxford, Elsevier.

Salmon, Vivian, 1985. "The study of foreign languages in seventeenth-century England", Histoire Épistémologie Langage, VII:2, 45-70.

Trask, R. L. 1996. Historical Linguistics. London: Arnold.

Vogel, J. Ph., 1935. "Jean Josua Ketelaar of Elbing, author of the first Hindustānī grammar", Bulletin of the School of African and Oriental Studies VIII, 817-822. University of London (reprint 1964).

- 1941. De eerste 'grammatica' van het hindostansch [the first Hindī "grammar"]. Amsterdam, Noord-Hollandsche Uitgevers Maatchappij, Nieuwe Reeks, Deel 4: II, 643-675.

Yates, William, 1827. Introduction to the Hindustani Language in Three Parts, Calcutta, The Baptist Press. 